\title{
A New Species of Freshwater Bopyrid, Probopyrus iriomotensis (Crustacea: Isopoda), Parasitizing Macrobrachium spp. (Crustacea: Decapoda), from Iriomote Island, Ryukyu Islands, Southwestern Japan
}

\author{
Nobuhiro Saito ${ }^{1}$, Shigemitsu Shokita ${ }^{2}$ and Tohru Naruse ${ }^{3}$ \\ ${ }^{1}$ Suido-sha Co. Ltd., Ikuta 8-11-11, Tama-ku, Kawasaki, Kanagawa, 241-0038 Japan \\ E-mail: nsaitoh@suidosha.co.jp \\ ${ }^{2}$ Okinawa Study Center, The Open University of Japan, 1 Senbaru, \\ Nishihara, Okinawa, 903-0213 Japan \\ ${ }^{3}$ Transdisciplinary Research Organization for Subtropical and Island Studies, \\ University of the Ryukyus, 870 Uehara, Taketomi, Okinawa, 907-1541 Japan \\ E-mail: naruse@lab.u-ryukyu.ac.jp
}

(Received 7 September 2009; Accepted 7 June 2010)

\begin{abstract}
A new species of bopyrid isopod, Probopyrus iriomotensis sp. nov. parasitizing palaemonid freshwater shrimps of the genus Macrobrachium, is described based on material from Iriomote Island, Ryukyu Islands, southwestern Japan. The new species most commonly infects the branchial chambers of Macrobrachium shokitai Fujino and Baba, 1973, but rarely also M. formosense (Bate, 1868). The new species is similar to Probopyrus ascendens (Semper, 1880), P. gangeticus Chopra, 1923, and P. giardi Weber, 1892, but can be distinguished from them by a combination of characters of the pleomere and pleotelson, relative body width, and the degree of deflection of the body axis. This is the first species of Bopyridae to be recorded from a freshwater environment in Japan. In addition, the generic assignment of two marine species of Probopyrus is questioned, and the date of authorship of $P$. marinus Nierstrasz and Brender à Brandis, 1923 is clarified.

Key Words: Crustacea, Isopoda, Bopyridae, Probopyrus, Macrobrachium, Iriomote Island, Japan.
\end{abstract}

\section{Introduction}

In Japan, 94 species of bopyrid isopod have been recorded (Shiino 1972; Saito et al. 2000; Shimomura et al. 2006). Although these species infect various groups of decapod crustaceans inhabiting marine or brackish-water environments, no true freshwater species has been known from Japan. Carcinologists of the University of the Ryukyus recently noticed, however, an unidentified bopyrid species of the genus Probopyrus Giard and Bonnier, 1888 infecting the branchial chambers of Macrobrachium shokitai Fujino and Baba, 1973, an endemic freshwater shrimp of Iriomote Island, the largest and least disturbed of the Yaeyama Islands in the southern Ryukyu Islands. 
The genus Probopyrus (type species: Bopyrus ascendens Semper, 1880) is represented by 28 species from the Indo-West Pacific, East Pacific, and tropical and subtropical regions of the western Atlantic, which infect mostly brackish- or freshwater palaemonid shrimps, including species of Macrobrachium, Cuapetes, Leander, Palaemon, and Palaemonetes (Shiino 1973; Markham 1985a; Román-Contreras and Bourdon 2001; Boyko and Schotte 2009; see "Discussion") (Table 1).

In this report, we describe the new species of Probopyrus infecting Macrobrachium shokitai under the name of $P$. iriomotensis. The new species is morphologically similar to $P$. ascendens (Semper, 1880), $P$. gangeticus Chopra, 1923, and $P$. giardi Weber, 1892. Distinguishing characters between $P$. iriomotensis sp. nov. and the latter three allied species are discussed. The present new species is the first freshwater bopyrid species known from Japan.

\section{Materials and Methods}

Specimens of Macrobrachium shokitai and M. formosense (Bate, 1868), the host shrimps of the new species of Probopyrus, were collected with hand-nets at Iriomote Island, preserved in $70 \%$ ethanol, and transported to the laboratory. The branchial chambers and pleons of the Macrobrachium shrimps were examined under a binocular microscope (Olympus X-II) to detect and extract bopyrid specimens. Measurements and drawings were made with the aid of a microscope (Olympus BHB-Tr) with an attached drawing tube.

Measurements provided are the body length (BL: measured along the major axis of the body) of the bopyrid specimens and the postorbital carapace length (CL: measured from the posterior margin of the orbit to the midpoint of the posterodorsal margin of the carapace) of the host shrimps. Other measurements and terminology essentially follow those of Markham (1985a) for bopyrids and Baba et al. (1986) for shrimps. The examined specimens are deposited in the Toyama Science Museum (TOYA Cr), Toyama, Japan; the Kitakyushu Museum of Natural History and Human History (KMNH IvR), Kitakyushu, Japan; and the Ryukyu University Museum, Fujukan (RUMF-ZC), Nishihara, Okinawa, Japan.

\section{Taxonomy}

Genus Probopyrus Giard and Bonnier, 1888

Probopyrus iriomotensis sp. nov.

[New Japanese name: Shokitatenaga-no-erayadori]

(Figs 1-3)

Material examined. Holotype: female (BL $8.6 \mathrm{~mm}$ ), TOYA Cr-15308, Kanpire Waterfall, Urauchi River, Iriomote Island, Ryukyu Islands, southwestern Japan, left branchial chamber of host (Macrobrachium shokitai, TOYA Cr-15310), 16 March 2002, coll. A. Ito et al. Allotype: male (BL $1.8 \mathrm{~mm}$ ), TOYA Cr-15309, removed from pleon of holotype.

Paratypes: female (BL $4.4 \mathrm{~mm}$ ), KMNH IvR 500,390, and male (BL $1.4 \mathrm{~mm}$ ) attached to its pleon, KMNH IvR 500,391, left branchial chamber of host; female (BL 
New Probopyrus from Iriomote Island

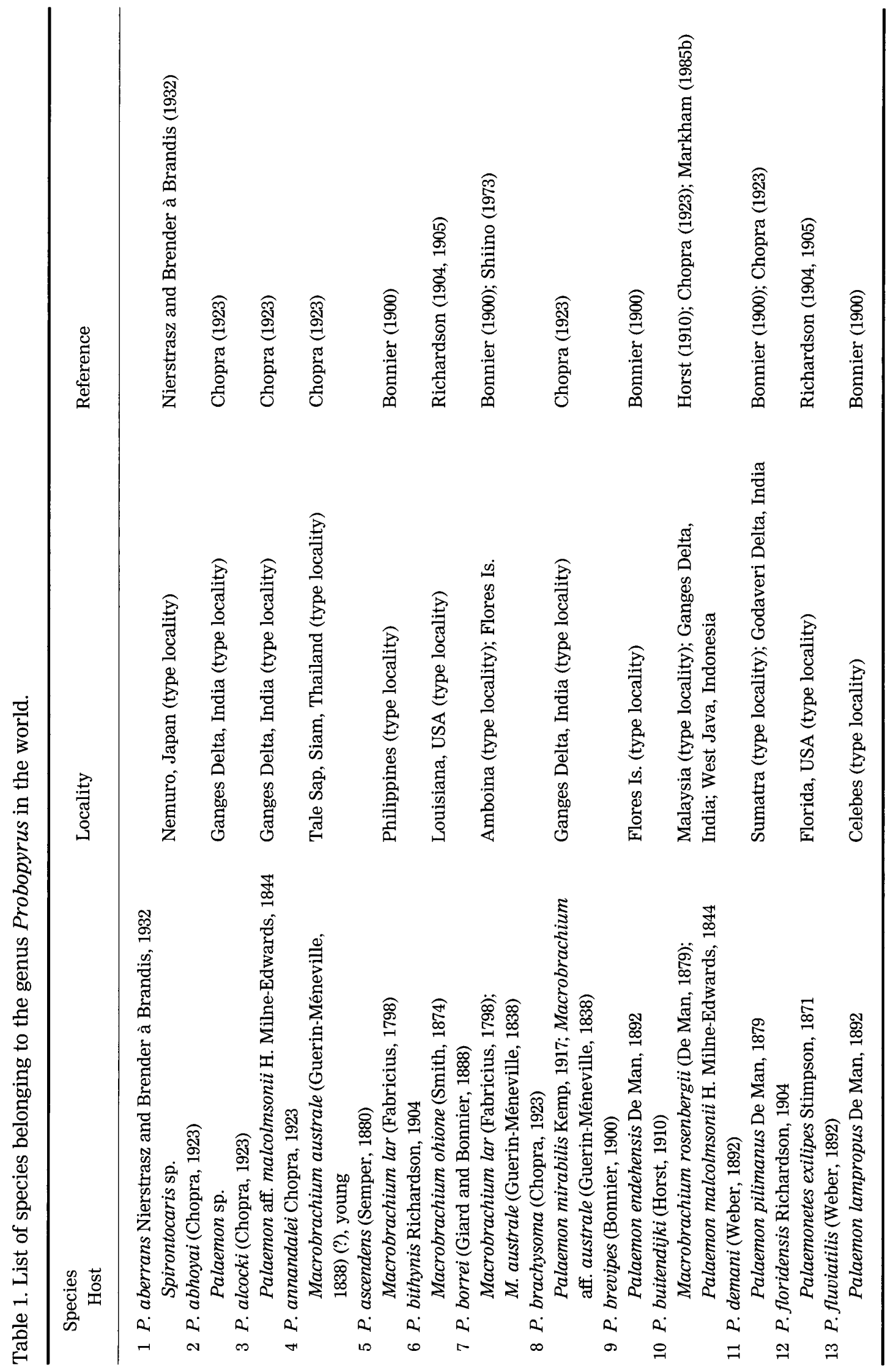









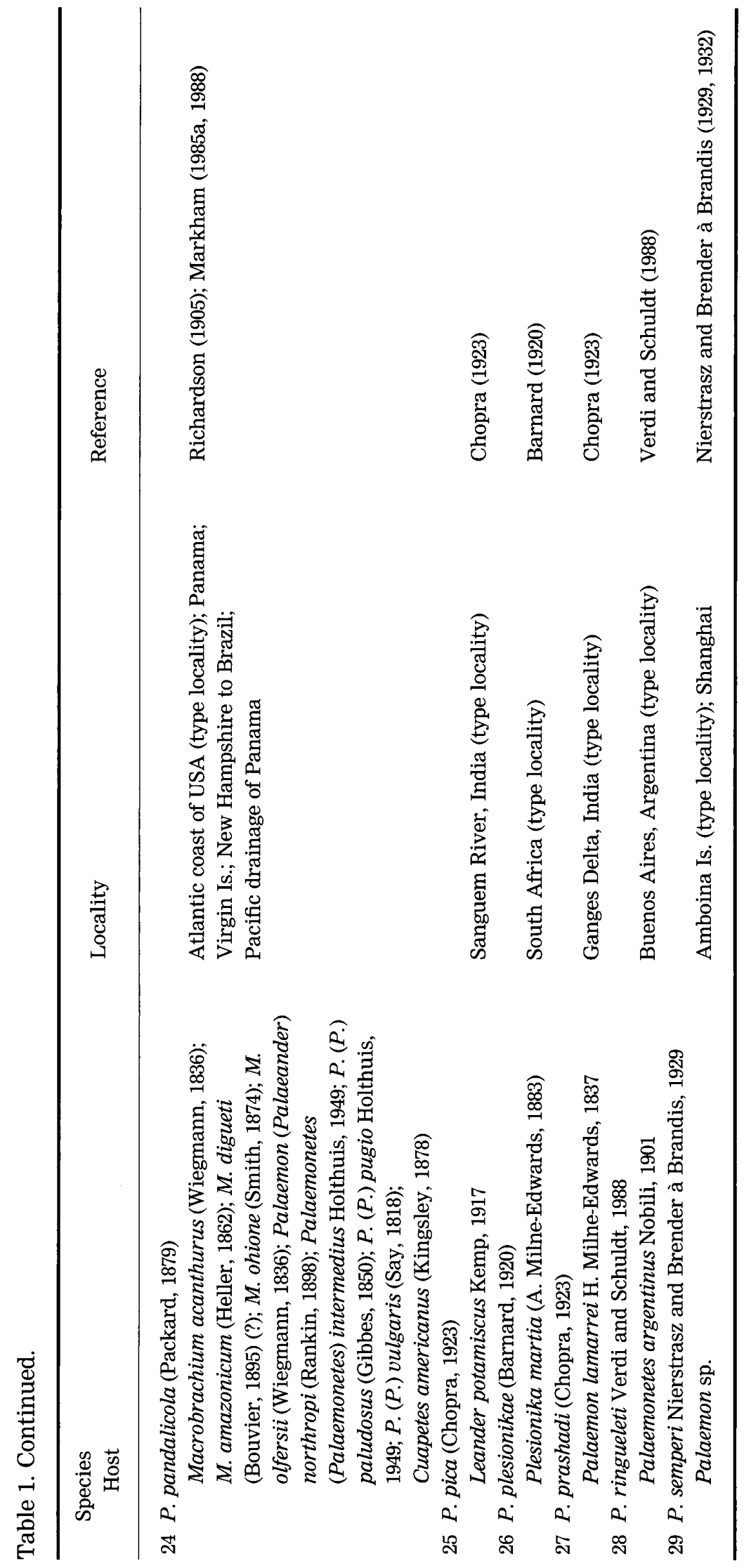



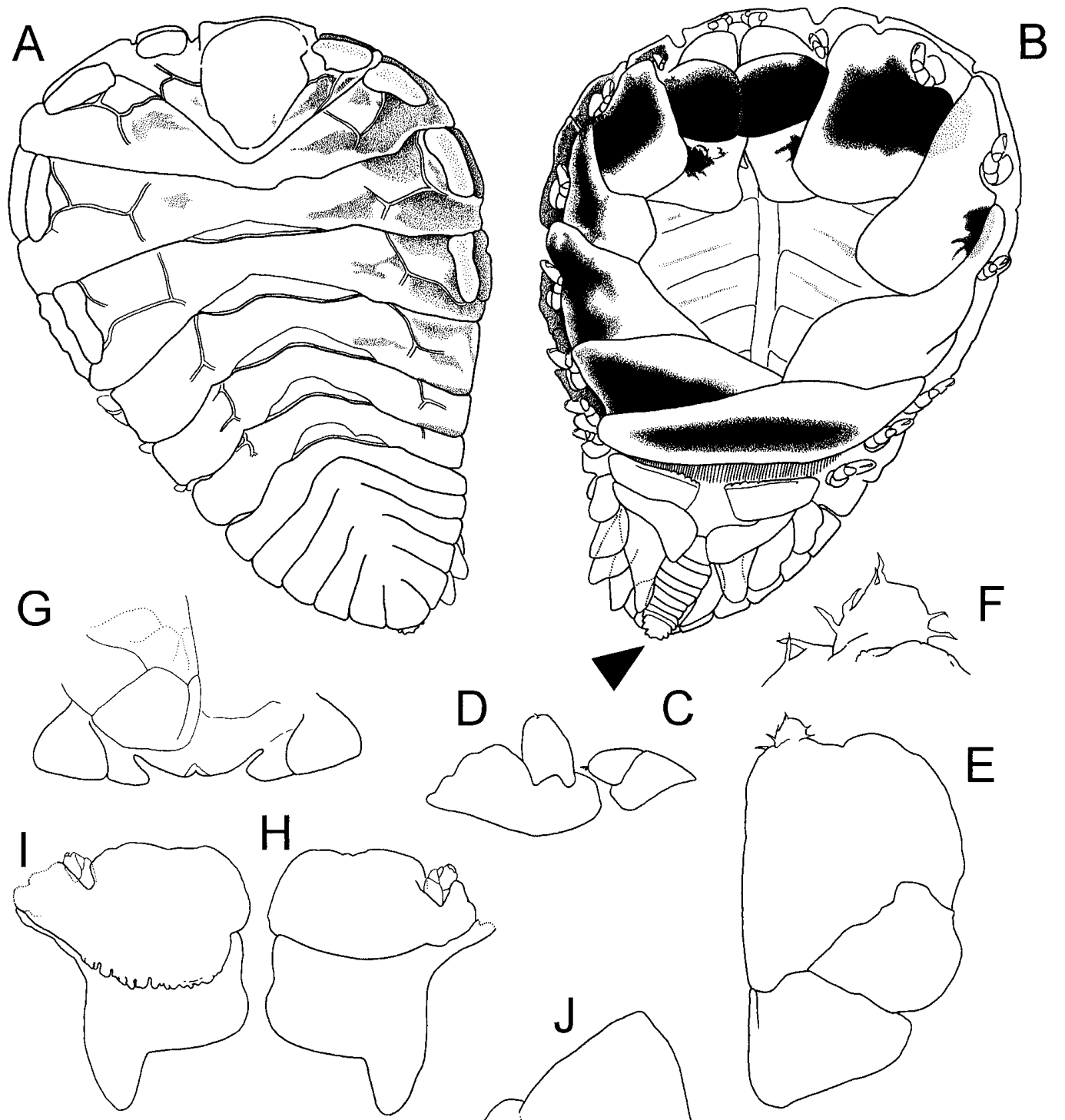

$\mathrm{H}$


Fig. 1. Probopyrus iriomotensis sp. nov., holotype, female (BL $8.6 \mathrm{~mm}$ ), TOYA Cr-15308. A, Entire animal, dorsal view; B, same, ventral view, showing attached dwarf male (allotype) on ventral side of pleon (arrowhead); C, right antenna 1, ventral view; D, right antenna 2, ventral view; E, left maxilliped, ventral view; F, palp of maxilliped; G, barbula, ventral view; $H$, left oostegite 1, ventral view; I, same, dorsal view; J, left pereopod 1, medial view; $\mathrm{K}$, left pereopod 7, medial view. 
A

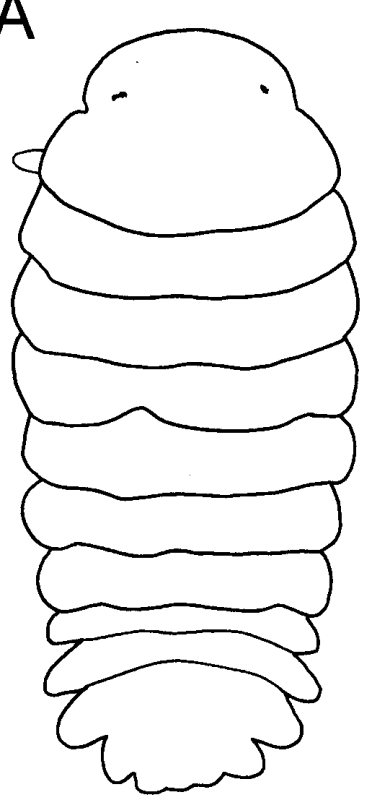

B

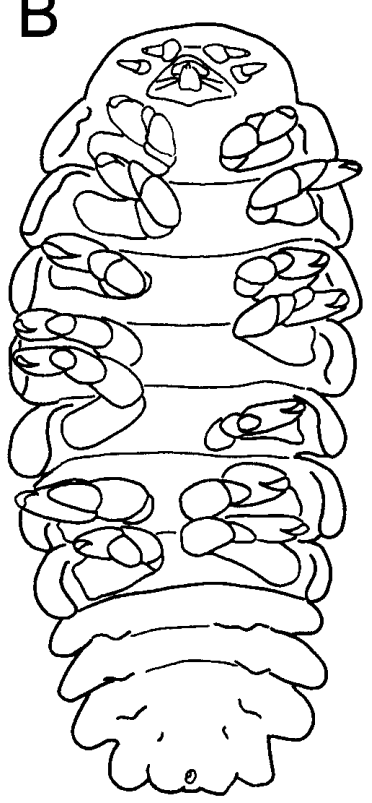

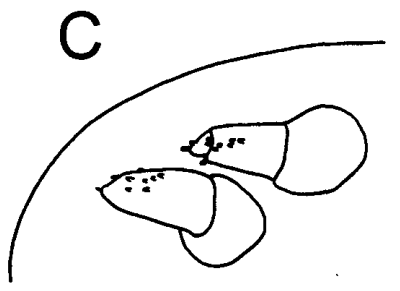
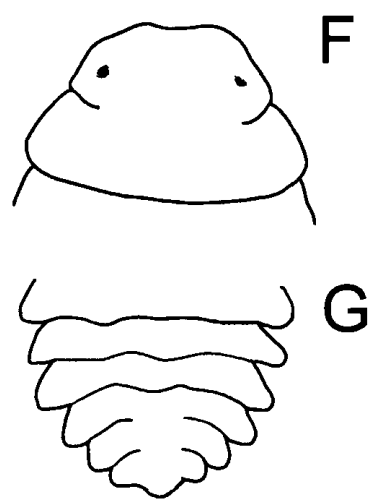
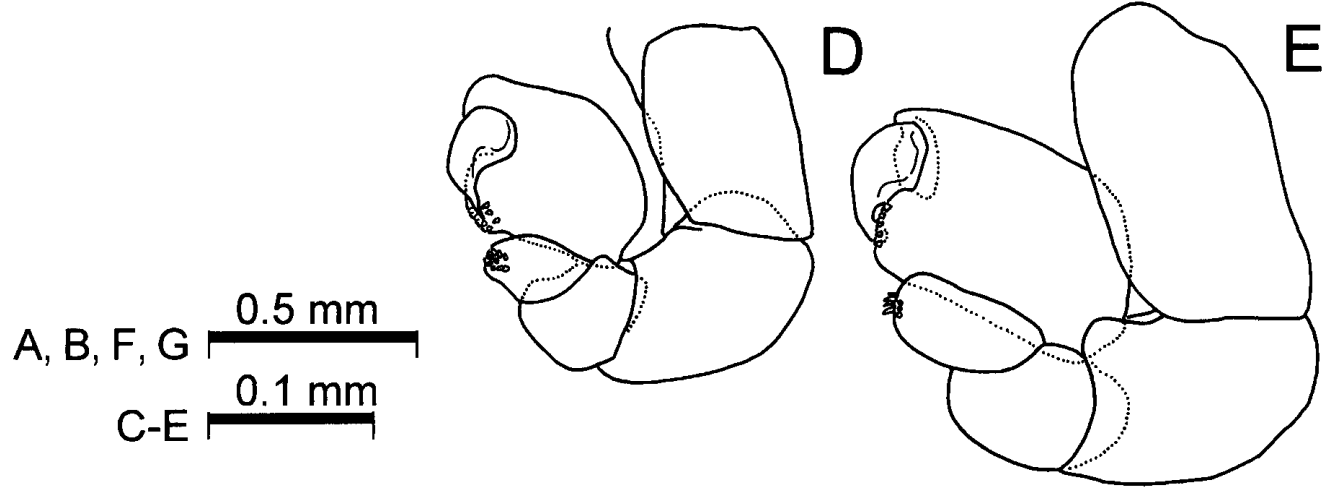

Fig. 2. Probopyrus iriomotensis sp. nov., allotype, male (BL $1.8 \mathrm{~mm}$ ), TOYA Cr-15309 (A-E) and paratype, male (BL 1.8 mm), KMNH IvR 500,393 (F, G). A, Entire animal, dorsal view; B, same, ventral view; $\mathrm{C}$, anteroventral view of head with right antennae 1 and 2; D, left pereopod 1 , medial view; E, left pereopod 7, medial view; F, head and pereomere 1, dorsal view; G, peleon, dorsal view.

$5.7 \mathrm{~mm}$ ), KMNH IvR 500,392, and male (BL $1.8 \mathrm{~mm}$ ) removed from its pleon, KMNH IvR 500,393, right branchial chamber of host, same data as holotype. Ovigerous female (BL 5.5 mm), RUMF-ZC-900, and male (BL $1.5 \mathrm{~mm}$ ) attached to its pleon, RUMF-ZC-901, left branchial chamber of host; ovigerous female (BL $7.6 \mathrm{~mm}$ ), RUMF-ZC-903, and male (BL $1.9 \mathrm{~mm}$ ) removed from its pleon, RUMF-ZC-904, right branchial chamber of host, Nishifunatsuki, tributary of Nakama River, Iriomote Island, Ryukyu Islands, southwestern Japan, 23 January 2004, coll. T. Naruse. Female (BL $9.8 \mathrm{~mm}$ ), with attached male on pleon, RUMF-ZC-01045, right branchial chamber of host; ovigerous female (BL $10.3 \mathrm{~mm}$ ), RUMF-ZC-01047, with no attached male, right branchial chamber of host; ovigerous female (BL $11.1 \mathrm{~mm}$ ), RUMF-ZC01043, with no attached male, right branchial chamber of host, Kanpire Waterfall, 


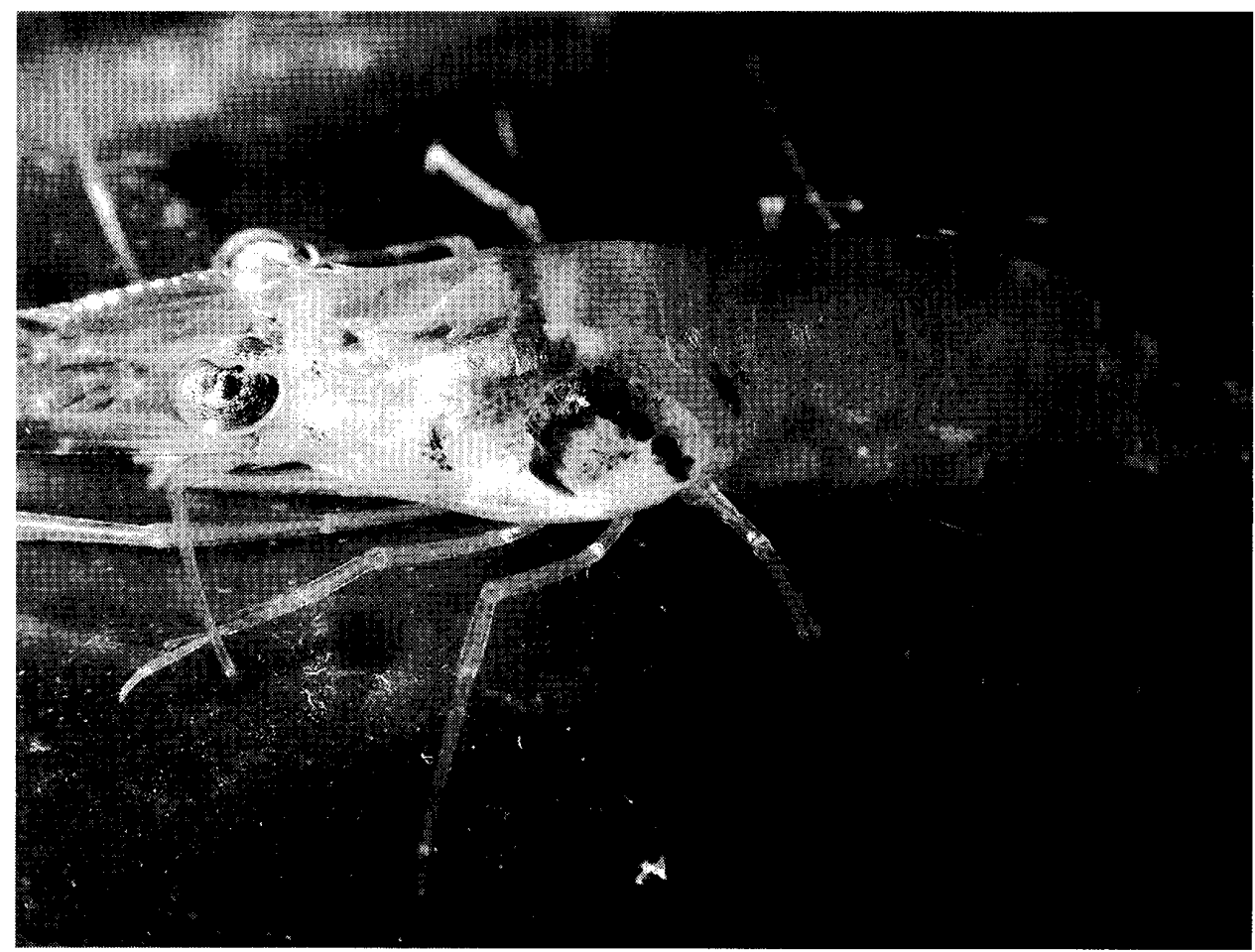

Fig. 3. Macrobrachium shokitai Fujino and Baba, 1973, male (CL 7.6 mm), KMNH IvR 500,394, infected by Probopyrus iriomotensis sp. nov. in the left branchial chamber.

Urauchi River, Iriomote Island, Ryukyu Islands, southwestern Japan, 11 July 2009, coll. T. Naruse.

Host specimens. Macrobrachium shokitai (all specimens immature): male (CL $12.8 \mathrm{~mm}$ ), TOYA Cr-15310, infected by holotype female (TOYA Cr-15308) and allotype male (TOYA Cr-15309); male (CL 7.6 mm), KMNH IvR 500,394, infected by paratype female and male (KMNH IvR 500,390 and 500,391); male (CL $8.9 \mathrm{~mm}$ ), KMNH IvR 500,395, infected by paratype female and male (KMNH IvR 500,392 and 500,393), Kanpire Waterfall, Urauchi River, Iriomote Island, Ryukyu Islands, southwestern Japan, 16 March 2002, coll. A. Ito et al. Male (CL $8.7 \mathrm{~mm}$ ), RUMF-ZC-902, infected by paratype female and male (RUMF-ZC-900 and -901); male (CL 10.0 mm), RUMF-ZC-905, infected by paratype female and male (RUMF-ZC-903 and -904), Nishifunatsuki, tributary of Nakama River, Iriomote Island, Ryukyu slands, southwestern Japan, 23 January 2004, coll. T. Naruse. Male (CL 11.4 mm), RUMFZC-01044, infected by paratype female and male (RUMF-ZC-01045); male (CL 11.5 $\mathrm{mm}$ ), RUMF-ZC-01046, infected by paratype female (RUMF-ZC-01047), Kanpire Waterfall, Urauchi River, Iriomote Island, Ryukyu Islands, southwestern Japan, 11 July 2009, coll. T. Naruse.

Macrobrachium formosense: male (CL $14.2 \mathrm{~mm}$ ), RUMF-ZC-01042, infected by paratype female (RUMF-ZC-01043), Kanpire Waterfall, Urauchi River, Iriomote Island, Ryukyu Islands, southwestern Japan, 11 July 2009, coll. T. Naruse.

Description of female holotype. Body compressed dorsoventrally, semioval in general outline, distinctly asymmetrical, with anterior margin nearly straight; 
body axis deflection $26^{\circ}$; maximal width at pereomere 3 , equal to $77 \%$ of body length.

Head (Fig. 1A) distinctly demarcated from pereon, but deeply embraced in pereomere 1 dorsally, head length $20 \%$ of body length; anterior margin slightly extending beyond that of pereomere 1, lacking frontal lamina; eyes absent. Both antennae 1 and 2 (Fig. 1C, D) 2-segmented. Maxillipeds (Fig. 1E, F) with short, non-articulated, setose palp and prominent spur. Barbula (Fig. 1G) with 2 pairs of lateral projections, outer one broad and blunt, inner one long and slender, and with medial " $\mathrm{v}$ "-shaped tiny notch.

Pereomeres (Fig. 1A) distinctly separated dorsally and laterally; anterior boundary of pereomere 3 nearly straight; posterior margins of pereomeres 1 and 2 convex, "U"-shaped; posterior margins of pereomeres 4 to 7 concave, inverted "U"shaped. Dorsolateral bosses and coxal plates present on both sides of pereomeres 1 to 4 . Oostegites (Fig. 1B) surrounding ventral side of margin of pereomeres, but incompletely enclosing brood pouch; oostegite 1 (Fig. $1 \mathrm{H}, \mathrm{I})$ prominently produced into rounded posterolateral point, with internal ridge dentate. Pereopods (Fig. 1J, $\mathrm{K}$ ) all subequal, relatively small, with all articles distinct; basis stout, with inner margins forming expanded carina; ischium rectangular; merus and carpus triangular; propodus trapezoidal; dactylus stout.

Pleon (Fig. 1A) length $32 \%$ of body length; pleomeres 1 and 2 clearly demarcated, pleomeres 2 to 5 and pleotelson with medial portions fused, notched laterally; each pleomere with pair of well-developed, flap-like, biramous pleopods, these reaching beyond lateral margins of pleon in concave side in situ, last pair smallest; uropods absent. Pleotelson sub-triangular, posterior margin rounded, smooth, without cleft or anal cone.

Description of male allotype. Body small, about $20 \%$ of that of female in length; elliptical in general outline; body width $46 \%$ of body length.

Head (Fig. 2A) fused with pereomere 1, semicircular, subequal in length to pereomere 1. Eyes small but conspicuous. Antennae (Fig. 2C) subequal in length; antenna 1 with 3 articles, and with short setae on anterior parts of distal 2 articles. Antenna 2 with 2 articles, proximal one having short setae.

All pereomeres (Fig. 2A) distinctly demarcated dorsally, no tubercles ventrally; lateral margins convex. Pereopods (Fig. 2D, E) all subequal, rather small; all articles distinct; palm of propodus with granules; distoventral tip of carpus with a few distal setae.

Pleon (Fig. 2A) length $25 \%$ of whole body length; pleomeres 1 and 2 clearly demarcated, pleomere 3 and following pleomeres completely fused; lateral margins of each pleon produced laterally, semicircular. Terminal pleomere short, with posterolateral margins and center of distal margin weakly expanded, forming "W"shape; uropods absent. Pleopods situated on posterolateral parts of pleomeres 1 to 4, sessile, tuberculiform (Fig. 2B).

Variation in male. One male paratype (KMNH IvR 500,393, BL $1.8 \mathrm{~mm}$ : Fig. $2 \mathrm{~F}, \mathrm{G})$ differing from other males in having slightly concave frontal cephalic margin, with head demarcated laterally from pereomere 1 , and pleomere 3 and following pleomeres also being demarcated laterally.

Coloration. Female in preservative. Ground color light yellowish brown. Head and dorsolateral bosses whitish in dorsal view; lateral parts of pereomeres 1-7 and coxal plates 2-4 with scattered dark pigment on concave side. Each side of oostegites 1,2 , and 5 , and concave side of oostegites 3 and 4 black in ventral view; con- 
vex side of oostegite 4 with dark pigment spots. Ventral side of body (Fig. 3) with "C"-shaped marking corresponding to black parts of brood pouch.

Male in preservative. Ground color light yellowish brown; pereomeres more brownish. Eyes conspicuously blackish.

Ecological note. Most of the examined specimens of Probopyrus iriomotensis were found on specimens of Macrobrachium shokitai, the sole land-locked species of Macrobrachium in the Ryukyus, from the upper reaches of the Urauchi River and Nakama River (Fig. 3). The infected part of the carapace of the host shrimp, either the right or left branchial chamber, was strongly expanded, and it is very easy to recognize the infection even in the field. Female bopyrids were attached by their ventral side to the branchial chamber of the host, and were facing backward. The brood pouch of the isopod is closed by the cuticular membrane of the inner side of the host's carapace. Six females were found with one male each attached to the ventral side of the pleon (Fig. $1 \mathrm{~B}$; the arrowhead indicates the posterior end of a male). Two female bopyrids collected in January (RUMF-ZC-900 and RUMF-ZC-903) and two of three collected in July (RUMF-ZC-01043 and RUMF-ZC-01047) had spawned, but three collected in March (TOYA Cr-15308, KMNH IvR 500,390, and KMNH IvR 500,392) were not carrying eggs or larvae. All the infected $M$. shokitai examined in the present study were immature males (CL 7.6-12.8 $\mathrm{mm}$ ).

One individual of Macrobrachium formosense was infected by Probopyrus iriomotensis at the latter's type locality. This finding suggests that $P$. iriomotensis may infect other species of Macrobrachium as well, including amphidromous species, although the present observations indicate that this isopod most commonly infects the land-locked $M$. shokitai.

Distribution. Known only from Iriomote Island, Ryukyu Islands, Japan: upper reaches of Urauchi River and Nakama River, and Kanpire Waterfall.

Etymology. Named after the type locality, Iriomote Island, Ryukyu Islands, Japan.

\section{Discussion}

\section{Species diffenrentiation}

The diagnostic characters of Probopyrus pertain to the female: semi-oval body shape; head demarcated distinctly from pereon but deeply embedded into dorsal surface of first pereomore; presence of unarticulated palp on maxilliped; presence of two pairs of lateral projections on barbula; distinctly demarcated pereomeres; presence of small pereopods on all pereomeres; oostegites ventrally surrounding margins of pereomeres but not fully enclosing brood pouch; oostegite 1 produced into prominent posterolateral point; six distinctly demarcated pleomeres (with medial parts of some pleomeres fused) (Shiino 1973; Markham 1985a, b). The present new species agrees well with Probopyrus in every diagnostic respect. Females of Probopyrus iriomotensis lack any cleft or notch on the posterior margin of the pleotelson, and pleomere 1 is clearly differentiated from the more posterior pleomeres. They are thus similar to females of $P$. ascendens (Semper, 1880), P. gangeticus Chopra, 1923, and P. giardi Weber, 1892. These three species, however, lack clear demarcations of the pleomere 2 and the following segments (cf. Bonnier 1900, pl. 32, figs 1, 7; Chopra 1923, pl. 19, fig. 1). Furthermore, the new species can be separated 
from $P$. ascendens and $P$. giardi by its narrower body shape (body width $77 \%$ of body length in $P$. iriomotensis vs $102 \%$ in $P$. ascendens and $87 \%$ in $P$. giardi), and from $P$. gangeticus by the greater deflection of the body axis $\left(26^{\circ}\right.$ vs $\left.16^{\circ}\right)$.

The pigmentation of females of Probopyrus iriomotensis is similar to that of $P$. borrei (Giard and Bonnier, 1888), but the new species can be differentiated easily by the rounded and smooth posterior margin of the pleotelson (vs a deeply concave posterior margin in $P$. borrei), the undemarcated medial parts of pleomere 2 and the following segments (vs pleomere 2 and sometimes the following segments being demarcated even medially in $P$. borrei), and the blunt shape of the two lateral projections on the barbula (vs hook-shaped in $P$. borrei) (cf. Shiino 1973, figs 1-4).

Although 15 atyid and 13 palaemonid species of freshwater shrimp have been recorded from Iriomote Island (Shokita 2003a, b; Fujita 2005; Cai and Shokita 2006), Probopyrus iriomotensis has been recorded only from $M$. shokitai and $M$. formosense. Macrobrachium shokitai is the only species of the genus known from the Ryukyus that has a land-locked life history and abbreviated larval development (Shokita 1973), and it has been categorized as "Vulnerable" or "Near Threatened" in three red data books issued by the Fisheries Agency, the Ministry of the Environment, and Okinawa Prefecture (Baba 1998; Shokita and Naruse 2005; Shokita 2006). It is interesting that all the infected specimens of $M$. shokitai were immature males. There is no information as to whether $P$. iriomotensis affects sex determination or growth of the host. As for other species of Probopyrus, Beck $(1979,1980)$ reported that $P$. floridensis Richardson, 1904 (as P. pandalicola (Packard, 1879)) infected females of Palaemonetes paludosus (Gibbes, 1850) in higher percentage than in males, but that only female hosts less than $31 \mathrm{~mm}$ in body length had a higher frequency of infection. Furthermore, the chelae of the infected male hosts were shorter than those of uninfected males, and most infected mature females were not ovigerous. Similarly, Probopyrus bithynis Richardson, 1904 was thought to have a detrimental effect on the reproductive capacity of female Macrobrachium ohione (Smith, 1874) (Truesdale and Mermilliod 1977). There are also a large number of freshwater palaemonid shrimps, including $M$. formosense, in Taiwan and China, but no bopyrid infections have been reported nor observed in them (J.-Y. Shy, Y. Cai, personal communications); however, Bonnier (1900) recorded Probopyrus ascendens (Semper, 1880) from Macrobrachium lar (Fabricius, 1798) in the Philippines. One of us (TN) also observed an infected Macrobrachium specimen in the RUMF collection (T. Naruse, unpublished data). Future study may reveal the presence of more bopyrid species infecting freshwater shrimps.

\section{Notes on species of Probopyrus}

According to Shiino (1973), Markham (1985a), Román-Contreras and Bourdon (2001), and Boyko and Schotte (2009), 26 previously described species are recognized in the genus Probopyrus. We would like to suggest that two more species should be recognized. Dale and Anderson (1982) showed that $P$. bithynis and $P$. floridensis are both distinct from $P$. pandalicola, being differentiated by larval characters. However, Markham (1985a: 27) considered all of them to be conspecific, commenting, "If they are distinct only as larvae, however, the separation into different species (or subspecies, or whatever) remains impossible and of little practical value for anyone working only with adults." Even though the separation may not be practical for taxonomists, the evidence from larval characters strongly sug- 
gests that $P$. bithynis and $P$. floridensis are valid species.

It is worth mentioning that Probopyrus aberrans Nierstrasz and Brender à Brandis, 1932 and P. plesionikae (Barnard, 1920) are substantially different from other species of Probopyrus in their morphogical and ecological traits. Probopyrus aberrans is characterized by a rectangular body shape and fairly reduced pleopods in females (vs semi-oval body shape and better developed pleopods in other species). Probopyrus plesionikae is unique in its elliptical body shape, complete (vs incomplete) enclosure of the brood pouch by oostegites, and 7-segmented antenna 2 (vs 2- or 3-segmented). Furthermore, these two species infect truly marine shrimps: $P$. aberrans can be found on Spirontocaris sp. (Hippolytidae), while P. plesionikae infects Plesionika martia (A. Milne-Edwards, 1883) (Pandalidae). As was noted above, species of Probopyrus usually infect fresh- or brackish-water shrimps. It will require careful rexamination to confirm the generic position of these two species. Since this issue is well outside of the scope of the present study, we tentatively leave them in Probopyrus for now.

Finally, although many authors have attributed the authorship of Probopyrus marinus to Nierstrasz and Brender à Brandis (1932), this species was originally described by them in 1923, not in 1932, as a species of Palaegyge Carus, 1888 (Nierstrasz and Brender à Brandis 1923).

\section{Acknowledgements}

We are grateful to Noboru Nunomura (Toyama Science Museum) and Michitaka Shimomura (Kitakyushu Museum of Natural History and Human History) for making helpful suggestions to early drafts of this paper; and to Tomoyuki Komai (Natural History Museum and Institute, Chiba), Christopher B. Boyko (American Museum of Natural History), and an anonymous reviewer for their useful comments on this manuscript. We sincerely thank Kazunari Ogawa (Z. Nakai Laboratory), Gyo Itani (Faculty of Education, Kochi University), Kazuyoshi Hashizume (Kokusai Gakuin High School), Takeo Yamauchi (Toyama Institute of Health), and Seiichi Watanabe and Izumi Yamazaki (Department of Aquatic Bioscience, Tokyo University of Marine Science and Technology) for providing us with literature. We would also like to thank Akane Ito and her colleagues (University of the Ryukyus) for providing the material used in this study; Norikazu Shikatani (Nanjo City, Okinawa Prefecture), Jhy-Yun Shy (National Penghu University), and Yixiong Cai (National Parks Board, Singapore) for their unpublished information on parasitism by bopyrids on Macrobrachium species; and Yasuharu Kurata (Hokkaido Prefectural Government) and Kiwamu Kanemitsu (Ibaraki Prefectural Freshwater Fisheries Experimental Station) for their help in amassing relevant literature.

\section{References}

Baba, K. 1998. Macrobrachium shokitai. Pp. 366-367. In: Fisheries Agency, the Government of Japan (Ed.) Data Book of Rare Aquatic Animals and Plants of Japan. Japan Fisheries Resource Conservation Association, Tokyo. [In Japanese]

Baba, K., Hayashi, K. and Toriyama, M. 1986. Decapod Crustaceans from Continental Shelf 
and Slope around Japan. Japan Fisheries Resource Conservation Association, Tokyo, 336 pp. [In Japanese and English]

Barnard, K. H. 1920. Contributions to the crustacean fauna of South Africa. 6. Further additions to the list of marine Isopoda. Annals of the South African Museum 17: 319-438.

Beck, J. T. 1979. Population interactions between a parasitic castrator, Probopyrus pandalicola (Isopoda, Bopyridae), and one of its freshwater shrimp hosts, Palaemonetes paludosus (Decapoda: Caridea). Parasitology 79: 731-449.

Beck, J. T. 1980. The effects of an isopod castrator, Probopyrus pandalicola, on the sex characters of one of its caridean shrimp hosts, Palaemonetes paludosus. Biological Bulletin 158: 1-15.

Bonnier, J. 1900. Contribution à l'étude des Epicarides. Les Bopyridae. Travaux de l'Institut Zoologique de Lille et du Laboratoire de Zoologie Maritime de Wimereux 8: 1-478.

Boyko, C. B. and Schotte, M. 2009. Bopyridae. In: Schotte, M., Boyko, C. B., Bruce, N. L., Poore, G. C. B., Taiti, S., Wilson, G. D. F. (Eds) World Marine, Freshwater and Terrestrial Isopod Crustaceans Database. Accessed through: World Register of Marine Species at $<$ http://www.marinespecies.org/aphia.php?p=taxdetails\&id=1195 on 2009-11-16> [Online access: January 2010]

Cai, Y. and Shokita, S. 2006. Atyid shrimps (Crustacea: Decapoda: Caridea) of the Ryukyu Islands, southern Japan, with descriptions of two new species. Journal of Natural History 40: $2123-2172$.

Chopra, B. 1923. Bopyrid isopods parasitic on Indian Macrura. Records of the Indian Museum 25: 411-550.

Dale, W. E. and Anderson, G. 1982. Composition of morphologies of Probopyrus bithynis, $P$. floridensis, and P. pandalicola larvae reared in culture (Isopoda, Epicaridea). Journal of Crustacean Biology 2: 392-409.

Fujita, Y. 2005. Macrobrachium sp. P. 225. In: Nature Conservation Division, Department of Cultural and Environmental Affairs, Okinawa Prefectural Government (Ed.) Threatened Wildlife in Okinawa, Red Data Okinawa, 2nd Ed. (Animals). Nature Conservation Division, Department of Cultural and Environmental Affairs, Okinawa Prefectural Government, Naha. [In Japanese]

Giard, A. and Bonnier, J. 1888. Sur deux nouveau genres d'êpicarides (Probopyrus et Palaegyge). Bulletin Scientifique de la France et de la Belgique 19: 53-77.

Horst, R. 1910. Palaegyge Buitendijki, sp. nov., parasitic on Palaemon carcinus Fabr. from Java. Notes from the Leyden Museum 32: 67-70.

Lemos de Castro, A. and Brasil Lima, I. M. 1974. Crustáceos isopodos epicarídeos do Brasil. IX. Gênero Probopyus Giard e Bonnier. Revista Brasileira de Biologia 34: 209-217.

Markham, J. C. 1985a. A review of the bopyrid isopods infesting caridean shrimps in the northwestern Atlantic Ocean, with special reference to those collected during the Hourglass Cruises in the Gulf of Mexico. Memoires of the Hourglass Cruises 7: 1-156.

Markham, J. C. 1985b. Redescription and systematic remarks on Probopyrus buitendijki (Horst, 1910) (Isopoda, Bopyridae), parasitic on Macrobrachium rosenbergii (De Man) in southeast Asia. Journal of Crustacean Biology 5: 673-682.

Markham, J. C. 1988. Descriptions and revisions of some species of Isopoda Bopyridae of the north western Atlantic Ocean. Zoologische Verhandelingen 246: 2-63.

Markham, J. C. 1991. Redescriptions and new records of Isopoda Bopyridae (Crustacea) from Thailand. Raffles Bulletin of Zoology 39: 289-297.

Nierstrasz, H. F. and Brender à Brandis, G. A. 1923. Die Isopoden der Siboga-Expedition. II. Isopoda Genuina. I. Epicaridea. Siboga-Expeditie 32b: 57-121, pls 4-9. 
Nierstrasz, H. F. and Brender à Brandis, G. A. 1929. Papers from Dr. Th. Mortensen's Pacific Expedition 1914-16. 48. Epicaridea 1. Videnskabelige Meddelelser fra Dansk Naturhistorisk Forening i Kjøbenhavn 87: 1-44.

Nierstrasz, H. F. and Brender à Brandis, G. A. 1932 Alte und neue Epicaridea. Zoologischer Anzeiger 101: 90-100.

Richardson, H. 1904. Contributions to the natural history of the Isopoda. Proceedings of the United States National Museum 27: 1-89.

Richardson, H. 1905. A monograph on the isopods of North America. Bulletin of the United States National Museum 54: I-LIII+1-727.

Román-Contreras, R. 1993. Probopyrus pacificensis, a new parasite species (Isopoda: Bopyridae) of Macrobrachium tenellum (Smith, 1871) (Decapoda: Palaemonidae) of the Pacific coast of Mexico. Proceedings of the Biological Society of Washington 106: 689-697.

Román-Contreras, R. 1996. A new species of Probopyrus (Isopoda, Bopyridae), parasite of Macrobrachium americanum Bate, 1868 (Decapoda, Palaemonidae). Crustaceana 69: 204-210.

Román-Contreras, R. and Bourdon, R. 2001. Probopyrus insularis, a new species (Isopoda: Bopyridae), a parasite of Macrobrachium faustinum (Saussure de, 1857) (Decapoda: Palaemonidae), with criteria to differentiate species of Probopyrus. Proceedings of the Biological Society of Washington 114: 918-928.

Saito, N., Itani, G. and Nunomura, N. 2000. A preliminary check list of isopod crustaceans in Japan. Bulletin of the Toyama Science Museum 23: 11-107. [In Japanese with English abstract]

Shiino, S. M. 1972. [The Epicaridea (list of species) from Japan]. Kansai Shizenkagaku 24: 7-10. [In Japanese]

Shiino, S. M. 1973. On Probopyrus borrei (Giard et Bonnier), a freshwater bopyrid (Epicaridea: Isopoda) collected in Guadalcanal and New Britain by the Noona Dan Expedition 1961-62 and Galathea Expedition 1950-52. Science Report of Shima Marineland 2: $23-36$.

Shimomura, M., Ohtsuka, S. and Sakakihara, T. 2006. Two bopyrid isopods infesting caridean shrimp Hippolyte sp. in the Seto Inland Sea, western Japan (Crustacea: Peracarida). Bulletin of the Kitakyushu Museum of Natural History and Human History, Series A (Natural History) 4: 1-7.

Shokita, S. 1973. Abbreviated larval development of the fresh-water prawn, Macrobrachium shokitai Fujino et Baba (Decapoda, Palaemonidae) from Iriomote Island of the Ryukyus. Annotationes Zoologicae Japonenses 46: 111-126.

Shokita, S. 2003a. Atyidae. Pp. 249-254. In: Nishida, M., Shikatani, N. and Shokita, S. (Eds) The Flora and Fauna of Inland Waters in the Ryukyu Islands. Tokai University Press, Tokyo. [In Japanese]

Shokita, S. 2003b. Palaemonidae. Pp. 255-261. In: Nishida, M., Shikatani, N. and Shokita, S. (Eds) The Flora and Fauna of Inland Waters in the Ryukyu Islands. Tokai University Press, Tokyo. [In Japanese]

Shokita, S. 2006. Macrobrachium shokitai. P. 61. In: Ministry of the Environment (Ed.) Threatened Wildlife of Japan, Red Data Book 2nd ed., Volume 7, Invertebrata (except Insecta and Mollusca). Japan Wildlife Resource Center, Tokyo. [In Japanese]

Shokita, S. and Naruse, T. 2005. Macrobrachium shokitai. Pp. 202-203. In: Nature Conservation Division, Department of Cultural and Environmental Affairs, Okinawa Prefectural Government (Ed.) Threatened Wildlife in Okinawa, Red Data Okinawa, 2nd Ed. (Animals). Nature Conservation Division, Department of Cultural and Environmental Af- 
fairs, Okinawa Prefectural Government, Naha. [In Japanese]

Truesdale, F. M. and Mermilliod, W. J. 1977. Some observations on the host-parasite relationship of Macrobrachium ohione (Smith) (Decapoda, Palaemonidae) and Probopyrus bithynis Richardson (Isopoda, Bopyridae). Crustaceana 32: 216-220.

Verdi, A. C. and Schuldt, M. 1988. Descripcion y biologia de Probopyrus ringuelti n. sp. (Crustacea, Epicaridea, Bopyridae). Effectors sobre el hospedador Palaemonetes argentinus Nobili (Crustacea, Caridea, Palaemonidae). Anales de la Sociedad Cientifica Argentina 218: $15-26$. 